\title{
An evaluation of garnet-clinopyroxene geothermometry in granulites *
}

\author{
Craig A. Johnson ${ }^{1 * *}$, Steven R. Bohlen ${ }^{2}$, and Eric J. Essene ${ }^{3}$ \\ ${ }^{1}$ Department of Geological Sciences, The University of Michigan, Ann Arbor, Michigan 48109, USA \\ ${ }^{2}$ Department of Earth and Space Sciences, State University of New York, Stony Brook, New York 11794, USA \\ ${ }^{3}$ Department of Geological Sciences, The University of Michigan, Ann Arbor, Michigan 48109, USA
}

\begin{abstract}
Four new formulations of the garnet-clinopyroxene geothermometer (Ellis and Green 1979; Ganguly 1979; Saxena 1979; Dahl 1980) have been evaluated in the Adirondacks and five other granulite terranes using results from 94 mineral pairs. The Saxena and Ganguly formulations give temperatures that are generally $100-150^{\circ} \mathrm{C}$ above those constrained by phase equilibria and other independent thermometry while the empirical calibration of Dahl gives widely scattered, erratic results. Despite some scatter in the data, the Ellis and Green calibration appears to be more accurate and precise than the others and is the most useful garnet-clinopyroxene thermometer currently available for quantitative thermometry in granulites. All four formulations are sensitive to large variations $\left(>70-80^{\circ} \mathrm{C}\right)$ in temperature suggesting that problems with accuracy and precision can be improved with further refinement of model-based aspects of the thermometers.
\end{abstract}

\section{Introduction}

Petrologists have long sought a widely applicable geothermometer. As a result, there has been substantial effort in developing thermometers that depend on the distribution of a pair of cations or groups of cations between coexisting phases, the so-called $K_{D}{ }^{1}$ thermometers. An attractive aspect of these thermometers is their apparent simplicity of application, requiring only an analysis of coexisting phases. $\mathrm{K}_{D}$ thermometers are, perhaps, the most widely applied and yet the most poorly calibrated thermometers. The effects of extensive substitutions on $\mathrm{Mg}-\mathrm{Fe}$ distribution in such systems as biotite-garnet, hornblende-garnet and garnet-clinopyroxene have not been fully evaluated, and there has been little assessment of the accuracy and precision of these thermometers. For garnet-clinopyroxene $(\mathrm{Mg}-\mathrm{Fe})$ thermometry, several workers have recently begun to address the problems of $\mathrm{Mg}-\mathrm{Fe}$ distribution as a function of vari-

Offprint requests to: S.R. Bohlen

* Contribution No. 392 from the Mineralogical Laboratory, Department of Geological Sciences, The University of Michigan, Ann Arbor, MI. 48709, USA

** Present address: Department of Geology and Geophysics, Yale University, New Haven, Connecticut 06520, USA

$1 K_{D}$, the distribution coefficient, is defined as the ratio of cations in coexisting minerals. $K_{D \mathrm{Fe}-\mathrm{Mg}}^{\mathrm{gt}-\mathrm{cpx}}$ is calculated as $\left(X_{\mathrm{Fe}}^{\mathrm{gt}} / X_{\mathrm{Mg}}^{\mathrm{gt}}\right)$ $\left(X_{\mathrm{Fe}}^{\mathrm{cpx}} / X_{\mathrm{Mg}}^{\mathrm{cpp}}\right)$ able mineral composition in addition to $P$ and $T$, and four new calibrations have been published (Ellis and Green 1979; Ganguly 1979; Saxena 1979; Dahl 1980). If properly calibrated, the garnet-clinopyroxene thermometer would be of great value since the assemblage is found in an array of rock types spanning a broad temperature range, from $300-400^{\circ} \mathrm{C}$ eclogites to albite-epidote amphibolites, amphibolites, granulites to $1,200^{\circ} \mathrm{C}$ garnet peridotite. This potential underscores the need to carefully evaluate the accuracy and precision of the thermometer.

\section{Garnet-clinopyroxene geothermometry}

The temperature dependence of $\mathrm{Mg}-\mathrm{Fe}^{2+}$ exchange between garnet and clinopyroxene has long been recognized as a potential geothermometer. A number of workers (Banno and Matsui 1965; Coleman et al. 1965; Evans 1965a; Essene and Fyfe 1967; Lovering and White 1969; Banno 1970; Mysen and Heier 1972) noted the correlation between the distribution coefficient $\left(K_{D}\right)$ for the exchange reaction:

$$
\begin{array}{lc}
\mathrm{Mg}_{3} \mathrm{Al}_{2} \mathrm{Si}_{3} \mathrm{O}_{12} & +3 \mathrm{CaFeSi}_{2} \mathrm{O}_{6} \\
\text { pyrope } & \text { hedenbergite } \\
=\mathrm{Fe}_{3} \mathrm{Al}_{2} \mathrm{Si}_{3} \mathrm{O}_{12} & +3 \mathrm{CaMgSi}_{2} \mathrm{O}_{6} \\
\text { almandine } & \text { diopside }
\end{array}
$$

and equilibration temperatures of different eclogite types. In a review of over 300 localities, Irving (1974) showed that $K_{D, \mathrm{Fe}-\mathrm{Mg}}^{\mathrm{gt} \text {-cpx }}$ varies from greater than 25 for garnet-clinopyroxene pairs in blueschist terranes to nearly 1 in garnet peridotites, but noted that within a single terrane $K_{D}$ could vary substantially as the probable result of mineral zoning (Evans 1965b; Essene and Fyfe 1967; Dudley 1969; Bryhni and Griffin 1971). Several studies have been conducted to evaluate the $T$ dependence of $K_{D}$ and to quantify the effects of pressure and bulk composition. Mysen and Heier (1972) proposed an empirical calibration for the garnet-clinopyroxene thermometer $\left(T(\mathrm{~K})=2475 /\left(\ln K_{D}+0.781\right)\right)$ based on the estimated equilibration temperatures of a variety of eclogites. Mori and Green (1978) equilibrated several natural garnets and clinopyroxenes between $950-1,500^{\circ} \mathrm{C}$ and $30-40 \mathrm{~Kb}$ and derived the $T$ dependence of $K_{D}(T(\mathrm{~K})=$ $\left.2800 / \ln K_{D}+1.19\right)$ ) for garnet lherzolite compositions. Raheim and Green (1974) experimentally calibrated $K_{D}$ as a function of $P$ and $T$ for natural basaltic compositions crystallized in the eclogite field at $20-40 \mathrm{~Kb}$ and temperatures 
primarily in the range of $1,000-1,500^{\circ} \mathrm{C}(T(\mathrm{~K})=(3686+$ $\left.28.35 P(\mathrm{~Kb})) /\left(\ln K_{D}+2.33\right)\right)$. They noted that $K_{D}$ was not affected by whole rock $\mathrm{Mg} / \mathrm{Fe}$ ratio (from $\mathrm{Mg} /\left(\mathrm{Fe}^{2+}+\right.$ $\mathrm{Mg})=0.062-0.85$ ) but implied that $K_{D}$ had a substantial dependence on bulk composition. Raheim and Green concluded that $K_{D}$ was more sensitive to pressure than predicted from molar volume data (Banno 1970). Such a conclusion has stirred considerable debate and further work has shown that the magnitude of the pressure effect may itself by compositionally dependent (Wood 1975, 1976, 1977).

Additional studies have been conducted to evaluate the importance of various compositional parameters to $K_{D}$ and to experimentally, empirically, or theoretically formulate garnet-cpx thermometers applicable over a wide range of $P-T-X$. Ellis and Green (1979) experimentally calibrated the effect of $\mathrm{Ca}$ on $K_{D, \mathrm{Fe}-\mathrm{Mg}}^{\mathrm{gt}-\mathrm{cpx}}$ as

$$
\begin{aligned}
& T(\mathrm{~K}) \\
& =\left(3104 X_{\mathrm{Ca}}^{\mathrm{gt}}+3030+10.86 P(\mathrm{~Kb})\right) /\left(\ln K_{D}+1.9034\right)
\end{aligned}
$$

and deduced a pressure dependence of less than half of that determined by Raheim and Green. Ganguly (1979) and Dahl (1980) have examined the effects of $\mathrm{Mn}$ in addition to other variables, $\mathrm{Fe} / \mathrm{Mg}, \mathrm{Ca}$ and pressure. Ganguly's formulation,

$$
\begin{aligned}
& T(\mathrm{~K})=(4801+11.07 P(\mathrm{~Kb}) \\
& \left.+1586 X_{\mathrm{Ca}}^{\mathrm{gt}}+1308 X_{\mathrm{Mn}}^{\mathrm{tg}}\right) /\left(\ln K_{D}+2.93\right)
\end{aligned}
$$

is based on experimental and thermochemical data while Dahl's thermometer,

$$
\begin{aligned}
& T(\mathrm{~K})=\left(2482+1509\left(X_{\mathrm{Fe}}^{\mathrm{gt}}-X_{\mathrm{Mg}}^{\mathrm{gt}}\right)\right. \\
& \left.+2810 X_{\mathrm{Ca}}^{\mathrm{gt}}+2855 X_{\mathrm{Mn}}^{\mathrm{gt}}\right) / R \ln K_{D},
\end{aligned}
$$

has been empirically derived from a granulite terrane in southwest Montana (Dahl 1979). Saxena (1979) has developed a thermometer for the system $\mathrm{Na}_{2} \mathrm{O}-\mathrm{MgO}-\mathrm{FeO}-$ $\mathrm{MnO}-\mathrm{Al}_{2} \mathrm{O}_{3}-\mathrm{SiO}_{2}$ formulated as $T(\mathrm{~K})=(8288+$ $27.6 P(\mathrm{~Kb})+\mathrm{Q} 1-\mathrm{Q} 2) /\left(R \ln K_{D}+2.4083\right)$, where Q1 and Q2 are functions of garnet and clinopyroxene compositions respectively, based on available experimental and thermochemical data. Estimated confidence levels for these thermometers are generally $\pm 5 \%$ in the temperature range $800-1,200^{\circ} \mathrm{C}$, although the authors note that errors may be somewhat larger toward the low temperature end of this range as a result of the lack of extensive experimental data or well constrained thermochemical parameters at such temperatures. The effect of significant jadeite solution and accompanying cation ordering for low-temperature ecologites has not yet been accomodated by present thermometers. The thermometers apply to low $\mathrm{Na}, \mathrm{Cr}$ mineral compositions that encompass the vast majority of coexisting garnets and clinopyroxenes found in granulite terranes.

There are few rigorous, systematic evaluations of these thermometers. Bohlen and Essene (1980) applied Raheim and Green's thermometer to granulites in the Adirondacks. They found a significant dependence of $K_{D, \mathrm{Mg}}^{\mathrm{st}-\mathrm{Fe}}$ on $\mathrm{Mg} / \mathrm{Fe}$ ratio and concluded that the thermometer was imprecise and not useful in distinguishing small variations $\left(<70-100^{\circ} \mathrm{C}\right)$ in metamorphic T. Carswell and Gibb (1980) tested the formulations of Raheim and Green, Mori and Green, Ellis and Green, Ganguly and Saxena in garnet lherzolites, and concluded that the Mori and Green and Ellis and Green thermometers give more reasonable temperatures than those of other workers.

\section{Analytical procedures}

Most analyses of coexisting garnet-clinopyroxene were taken from the literature. However, data from the literature was used only if: 1) elemental oxide totals for the mineral analyses were $100 \pm 1.5 \%$ and the stoichiometries did not deviate by more than $2 \%$ in any cation site from ideal garnet or clinopyroxene mineral formulae, 2) authors had evaluated mineral homogeneity and analyses were obtained on locations within minerals that were broadly homogeneous (generally with variations of less than $2 \mathrm{~mol} \%$ of major element endmembers), 3) analyses were obtained from garnet-clinopyroxene pairs in physical contact in rocks that showed no evidence of extensive retrograde metamorphic effects ${ }^{1}$. The same selection criteria applied to our own data for Adirondack garnet-clinopyroxene pairs (Bohlen and Essene 1980; Johnson and Essene 1982). In order to evaluate garnet zoning, traverses of spot analyses were made on several Adirondack garnets in contact with clinopyroxene using the University of Michigan ARL-EMX electron microprobe equipped with LiF, PET, and TAP crystal spectrometers. At a given spot $\mathrm{Fe}, \mathrm{Mn}, \mathrm{Mg}, \mathrm{Si}$ and $\mathrm{Al}$ were measured using wavelength dispersive techniques; $\mathrm{Ca}$ was analyzed using a Kevex Li-drifted silicon detector. The data were corrected for atomic number, absorption, fluorescence, background and machine drift using the computer program EMPADR VII (Rucklidge and Gasparrini 1969). Counting times were approximately 60 seconds $(15 \mathrm{KV}$, $0.005-0.008 \mu \mathrm{A}$ sample current) to ensure that random errors associated with counting statistics are less than $1 \%$ for $\mathrm{Fe}$ and $\mathrm{Mg}$ and less than $2 \%$ for $\mathrm{Mn}$ and $\mathrm{Ca}$. For all of the analyses used in this study, garnet and clinopyroxene formulae were normalized about 8 and 4 cations respectively, and ferric iron was inferred from stoichiometry.

\section{Thermometry evaluation}

Field areas used to properly evaluate any thermometer should ideally satisfy several criteria. Temperature should be well constrained by both phase equilibria and by other independent thermometers, and should show variation (preferably $100^{\circ} \mathrm{C}$ ) across the terrane. Pressure should also be well constrained. The terrane should have a range of lithologies providing a wide variation in mineral compositions so that compositional dependencies of the thermometer being tested can be evaluated. A very restricted range of compositions may give false impressions of precision or accuracy of a given thermometer. In addition, the nature of the fluid phase, if any, should be well defined, even though the metamorphic fluid may have no direct effect on the thermometer. Finally, there should be no polymetamorphic, retrograde metamorphic, or other re-equilibration features present. Ideally the terrane should have equilibrated during a single thermal event with subsequent rapid cooling to quench in equilibrium composition.

In granulite terranes, these final considerations are difficult to evaluate. Investigations of Phanerozoic metamorphic terranes clearly show that regional metamorphism is a protracted event with more than one thermal-deformational period. It is unlikely that Precambrian terranes did

\footnotetext{
1 In some cases information concerning these criteria was not available in the publications from which the analyses were obtained. The necessary data were obtained through personal communications with the authors
} 
Table 1. Application of Garnet-clinopyroxene thermometry in Granulite Terranes

\begin{tabular}{|c|c|c|c|c|c|c|c|c|}
\hline Locality & Description & Data source & \# Samples & $\begin{array}{l}\text { Temperature } \\
\left({ }^{\circ} \mathrm{C}\right)\end{array}$ & Dahl & $\begin{array}{l}\text { Ellis and } \\
\text { Green }\end{array}$ & Ganguly & Saxena \\
\hline $\begin{array}{l}\text { Adirondack } \\
\text { Lowlands }\end{array}$ & $\begin{array}{l}\text { amphibolite } \\
\text { felsic granulite }\end{array}$ & $\begin{array}{l}\text { Stoddard (1976) } \\
\text { Bohlen and } \\
\text { Essene }(1980)\end{array}$ & 4 & 700 & $\begin{array}{l}672-768 \\
(725)^{a}\end{array}$ & $\begin{array}{l}652-734 \\
(696)\end{array}$ & $\begin{array}{l}760-804 \\
(790)\end{array}$ & $\begin{array}{l}730-813 \\
(769)\end{array}$ \\
\hline $\begin{array}{l}\text { Adirondack } \\
\text { Highlands }\end{array}$ & $\begin{array}{l}\text { felsic to mafic } \\
\text { granulites }\end{array}$ & $\begin{array}{l}\text { Bohlen and } \\
\text { Essene (1980) } \\
\text { Johnson and } \\
\text { Essene (1982) }\end{array}$ & 32 & $700-800$ & $\begin{array}{l}554-1276 \\
(870)\end{array}$ & $\begin{array}{l}690-941 \\
(785)\end{array}$ & $\begin{array}{l}776-1010 \\
(902)\end{array}$ & $\begin{array}{l}721-1064 \\
(926)\end{array}$ \\
\hline $\begin{array}{l}\text { Bukesfjurden } \\
\text { Area, } \\
\text { SW Greenland }\end{array}$ & $\begin{array}{l}\text { mafic } \\
\text { granulites }\end{array}$ & Wells (1979) & 6 & $750-800$ & $\begin{array}{l}733-892 \\
(800)\end{array}$ & $\begin{array}{l}702-762 \\
(733)\end{array}$ & $\begin{array}{l}816-858 \\
(839)\end{array}$ & $\begin{array}{l}699-1005 \\
(906)\end{array}$ \\
\hline $\begin{array}{l}\text { Doubtful Sound, } \\
\text { New Zealand }\end{array}$ & $\begin{array}{l}\text { deep crustal } \\
\text { mafic granulites }\end{array}$ & Oliver (1977) & 5 & 750 & $\begin{array}{l}787-1004 \\
(933)\end{array}$ & $\begin{array}{l}802-901 \\
(868)\end{array}$ & $\begin{array}{l}881-980 \\
(944)\end{array}$ & $\begin{array}{l}790-995 \\
(851)\end{array}$ \\
\hline $\begin{array}{l}\text { Furua } \\
\text { Complex, } \\
\text { Tanzania }\end{array}$ & $\begin{array}{l}\text { felsic to mafic } \\
\text { granulites } \\
\text { (Zones B and C) }\end{array}$ & Coolen $(1980)$ & 30 & $750-800$ & $\begin{array}{l}690-950 \\
(860)\end{array}$ & $\begin{array}{l}736-813 \\
(762)\end{array}$ & $\begin{array}{l}801-943 \\
(862)\end{array}$ & $\begin{array}{l}824-951 \\
(895)\end{array}$ \\
\hline $\begin{array}{l}\text { Otter Lake } \\
\text { Area, } \\
\text { S. Quebec }\end{array}$ & $\begin{array}{l}\text { felsic to mafic } \\
\text { granulites }\end{array}$ & Perkins (1979) & 7 & $675-700$ & $\begin{array}{l}612-737 \\
(674)\end{array}$ & $\begin{array}{l}663-697 \\
(675)\end{array}$ & $\begin{array}{l}754-791 \\
(781)\end{array}$ & $\begin{array}{l}837-896 \\
(871)\end{array}$ \\
\hline $\begin{array}{l}\text { Ruby Range, } \\
\text { Montana }\end{array}$ & $\begin{array}{l}\text { pelitic, mafic } \\
\text { granulites, } \\
\text { Fe-formation }\end{array}$ & Dahl (1980) & $\begin{array}{l}5 \\
\text { (low Mn) } \\
4 \\
\text { (high Mn) }\end{array}$ & $\begin{array}{l}750 \\
750\end{array}$ & $\begin{array}{l}723-785^{* *} \\
(752) \\
710-769 \\
(745)\end{array}$ & $\begin{array}{l}730-802 \\
(764) \\
611-677 \\
(648)\end{array}$ & $\begin{array}{l}810-849 \\
(830) \\
791-809 \\
(800)\end{array}$ & $\begin{array}{l}792-827 \\
(808) \\
790-836 \\
(805)\end{array}$ \\
\hline
\end{tabular}

a Values in parentheses are averages

b The Ruby Range Montana is the field area in which Dahl's thermometer was empirically calibrated

not similarly evolve. In addition, rapid cooling seems unlikely since many granulite terranes were buried in excess of 25 kilometers. Nevertheless, petrologic studies in a number of granulite terranes suggest that a single high $P-T$ regime is recorded in the mineral assemblages and chemistries without significant, pervasive retrogression. Evidence that minerals equilibrated during granulite facies metamorphism maintain their peak or near peak compositions during cooling and excavation is the general lack of zonation in pyroxenes, plagioclase, and garnets, in addition to the regular consistency of phase equilibria involving continuous and discontinuous reactions in a variety of lithologies. Mechanisms that might explain these phenomena might involve equilibration of the rocks during a fluid present prograde metamorphism with subsequent anatexis and intrusion of hydrous felsic magmas to higher levels, drying the rocks, and resulting in a vapor-absent retrograde metamorphism. This assumes that vapor-absent kinetics are several orders of magnitude slower than vapor-present conditions at granulite $P$ and $T$. If such a mechanism were viable, it might explain the preservation of peak or near peak mineral chemistries for metamorphic assemblages of diverse chemistry.

Proper evaluation of metamorphic temperatures has been a matter of much recent discussion (Dahl 1979; Stoddard 1980; Coolen 1980). Some workers have determined metamorphic $T$ by averaging the results from all applicable thermometers. Others have used all pertinent thermometers and chosen a temperature where the spread in temperatures from each thermometer overlap, the so-called consensus peak temperature. The averaging of thermometric data may be justified for a single thermometer if it can be demonstrated that the precision is poor but the average yields a reasonably accurate value. The averaging of results from different thermometers seems totally unjustified, and at best can only yield a very approximate estimate of $T$. Similarly, the consensus temperature approach may yield some rough approximation of temperature but almost guarantees an imprecise and probably inaccurate temperature estimate, and precludes evaluation of $T$ variation within a terrane. Metamorphic temperatures should be evaluated using the results of reaction equilibria and independent thermometry in an integrated fashion. With the above considerations in mind, we have attempted to evaluate the accuracy and precision of the four most recent and comprehensive formulations of the garnet-clinopyroxene geothermometer (Ellis and Green 1979; Ganguly 1979; Saxena 1979; Dahl 1980) in six different granulite terranes (Table 1).

The Adirondacks of upper New York State are a nearly ideal terrane in which to evaluate garnet-clinopyroxene thermometry. Garnet-clinopyroxene assemblages are common and span a wide range of compositions $(\mathrm{Mg} / \mathrm{Mg}+$ $\left.\mathrm{Fe}^{2+}\right)_{\mathrm{cpx}}=0.09-0.85$ ). The pressure-temperature framework of Adirondack metamorphism has been well established using a variety of mineral systems. Pressures are well known and have been widely discussed (Bohlen et al. 1980 b; Valley and Essene 1980; Bohlen and Boettcher 1981; Johnson and Essene 1982). Feldspar and oxide thermometry yield consistent and smoothly varying temperatures ranging from $600-650^{\circ} \mathrm{C}$ in the extreme northwest Adirondack Lowlands, to $750-800^{\circ} \mathrm{C}$ in areas surrounding the Marcy anorthosite, the Adirondack Highlands (Bohlen et al. 1980a). This regional picture is further corroborated by other thermometers. In the Balmat-Edwards district (NW Adirondacks) Brown et al. (1978) report a calcite-dolomite temperature of $625^{\circ} \mathrm{C}$ and just north of Mt. Marcy Valley and 
Essene (1980) report coexisting akermanite-wollastonitemonticellite that requires $T=750^{\circ} \pm 30^{\circ} \mathrm{C}$. In rocks adjacent to this locality, oxide and feldspar thermometry yield $770^{\circ} \pm 30^{\circ} \mathrm{C}$. Other temperature-sensitive systems support the regional trend defined by oxide and feldspar data. Valley and O'Neil (1981) show systematic, well-defined trends in fractionation of ${ }^{13} \mathrm{C}$ between calcite and graphite with the lowest fractionation occurring where oxides and feldspars indicate highest $T$ and increasingly greater fractionations as inferred $T$ decreases. In addition, a variety of phase equilibria in marbles, pelites, and orthogneisses are consistent with the oxide and feldspar data (Bohlen and Essene 1978 b; Bohlen et al. 1980 b; Valley and Essene 1980a, b). Recently, the oxide and feldspar $T$ data have been criticized as being too low because of the uncertainty associated with the reintegration techniques necessary to account for the effects of retrograde intracrystalline features (Stoddard 1980) and because feldspar and oxide temperatures are below those obtained by pyroxene thermometry (Coolen 1980). Where temperature data are sparse, it is possible that the feldspar and oxide $T$ could be somewhat low. In the area near Colton (Stoddard's field area) subsequent work (Edwards and Essene 1981) shows that oxide and feldspar temperatures are $700 \pm 20^{\circ} \mathrm{C}$, in agreement with Stoddard and some $20-50^{\circ} \mathrm{C}$ higher than the data of Bohlen et al. (1980a) that were based on only two temperature determinations, both $25-30 \mathrm{~km}$ from Colton. However, similar criticism of the data for the central Adirondack Highlands is untenable. The widespread occurrences of phlogopite-calcite-quartz, tremolite-calcite-quartz, grossular-rich garnet-quartz, and the absence of metamorphic pigeonite (Podpora and Lindsley 1979) in ortho- and paragneisses place severe constraints on maximum $T$. The maxima are consistently within $20-30^{\circ} \mathrm{C}$ above and below the $T$ inferred from other thermometers. Hence, the phase equilibria support the premise that the temperature data of Bohlen et al. (1980a) are peak or very near peak metamorphic temperatures.

Electron microprobe analyses of 43 garnet-clinopyroxene pairs (Stoddard 1976; Bohlen and Essene 1980; Johnson and Essene 1982) have been used to calculate Adirondack temperatures. The results of the Ellis and Green, Ganguly, Saxena and Dahl thermometers are shown in Figs. 1, 2,3 , and 4, respectively, and summarized in Table 1.

Comparison of Figs. 1 through 4 indicates that the Saxena formulation of the garnet-clinopyroxene thermometer yields temperatures that appear to be much too high as do the results of the Ganguly and Dahl calibrations, although perhaps to a lesser degree. Of the three, the Dahl calibration is the least precise. However, the Ellis and Green calibration appears to yield temperatures with slightly greater precision and, apart from a few notable exceptions, considerably greater accuracy. Despite substantial imprecision and apparent inaccuracy, the Saxena, Ganguly and Dahl thermometers seem capable of sensing large variations in temperature $\left(80-100^{\circ} \mathrm{C}\right.$ or more) such as those that exist between the central and northwest Adirondacks. Such a relative temperature variation could also have been inferred from the $K_{D}$ values of garnet-cpx pairs; 5 samples from the northwest have an average $K_{D}$ of 7.3 while those in the central Adirondacks average 5.3.

There are several potential causes for the problems with precision and/or accuracy in these thermometer calibrations. We have attempted to evaluate the potential problems

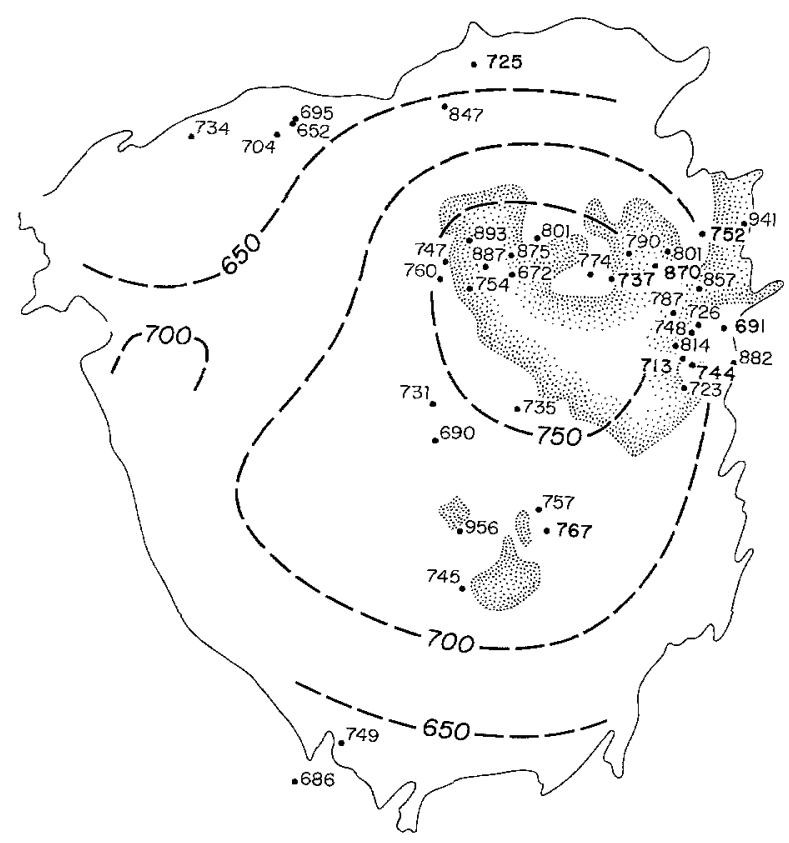

Fig. 1. Temperatures calculated from Ellis and Green formulation of garnet-clinopyroxene thermometry. Dashed curves are inferred isotherms of Bohlen et al. (1980a). Stippled areas are anorthosite masses. Map outlines the Precambrian terrane of Upper New York State

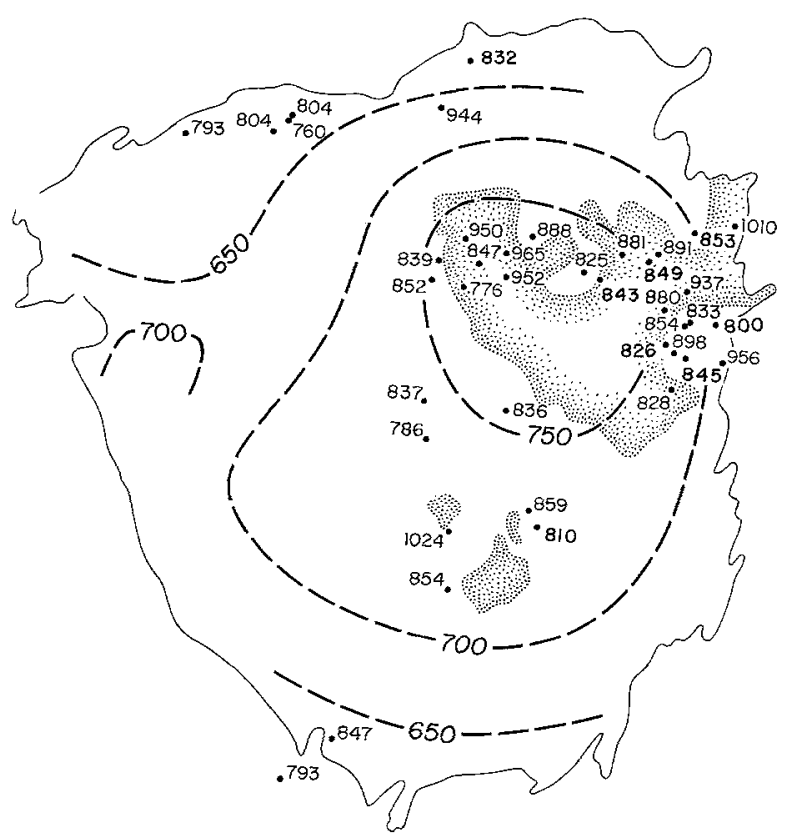

Fig. 2. Temperatures calculated from Ganguly formulation of garnet-clinopyroxene thermometry. Map outline, dashed curves and stippled areas same as in Fig. 1

arising from mineral zonation. The chemical profile of an Adirondack garnet is shown in Fig. 5. This profile was chosen from over a dozen different rocks, or in two cases, two profiles from different garnets in the same rock. It is similar to the other profiles but is exceptional in that it shows the greatest variation in compositions near the grain boundaries. It can be seen that there are very small compositional variations across the garnet. Almandine and pyrope components vary by $1-2 \mathrm{~mol} \%$ with some of the 


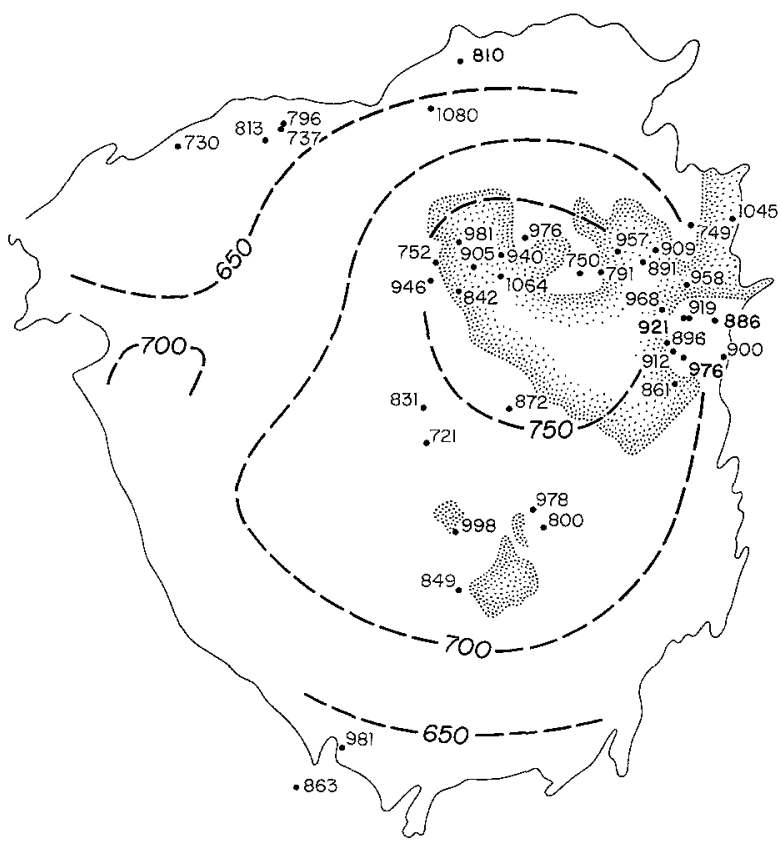

Fig. 3. Temperatures calculated from Saxena formulation of garnet-clinopyroxene thermometry. Map outline, dashed curves and stippled areas same as in Fig. 1

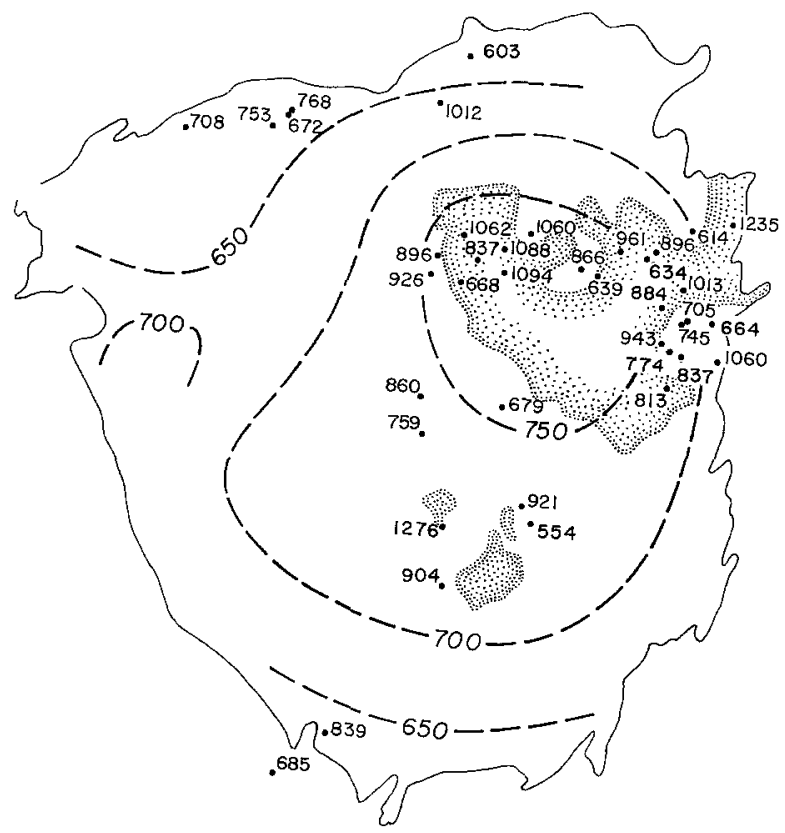

Fig. 4. Temperatures calculated from Dahl formulation of garnet-clinopyroxene thermometry. Map outline, dashed curves and stippled areas same as in Fig. 1
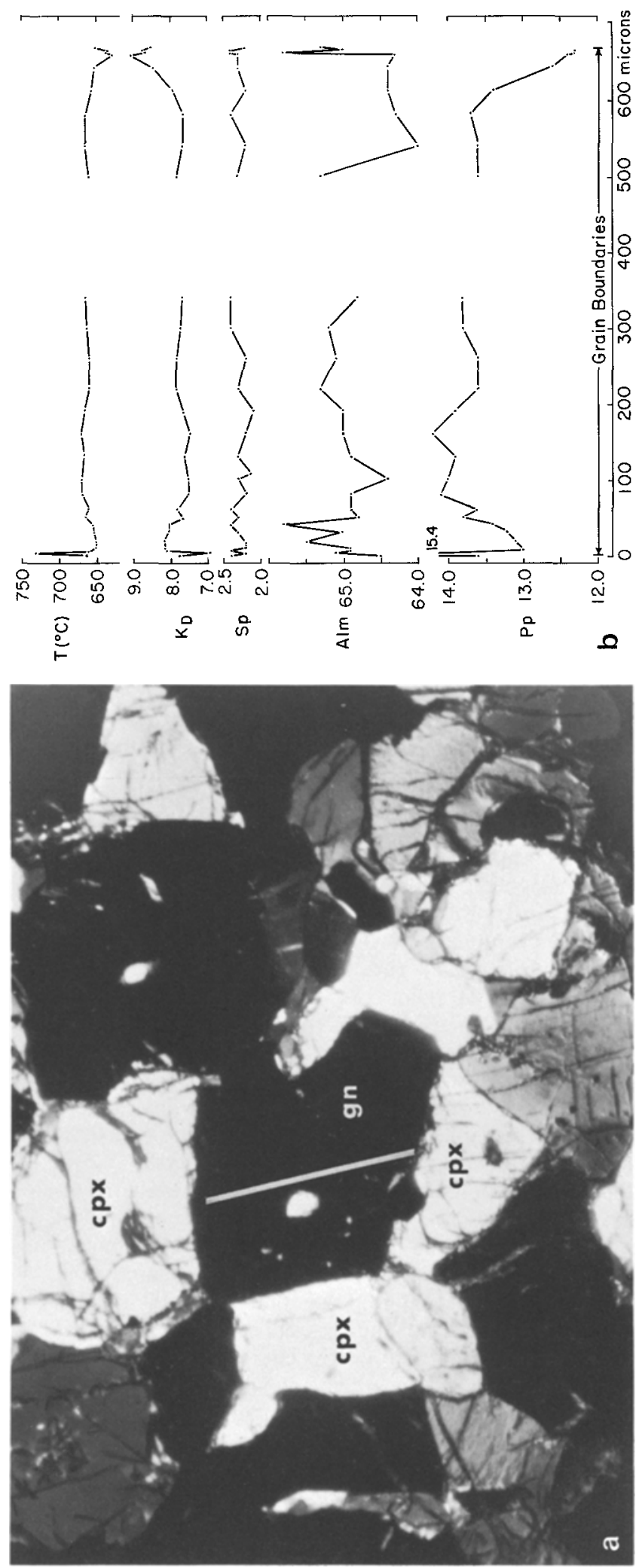

variation $(0.2-0.6 \mathrm{~mol} \%)$ attributable to counting statistics. Spessartine and grossular components remain essentially constant. The largest variations occur within 10-30 microns of the grain boundary, possibly signaling localized retrogression. Although these variations are small in absolute terms, their effect on calculated temperatures can be substantial, as indicated in Fig. 5. Clinopyroxenes, on the other hand, show remarkable homogeneity even near grain boundaries. Our analyses of Adirondack garnets represent averages of 6-10 points taken in areas away from the relatively inhomogeneous rims. Therefore, it is unlikely that much of the observed imprecision or inaccuracy can be attributed to the minor compositional variations found in Adirondack garnets. We have also attempted to evaluate 


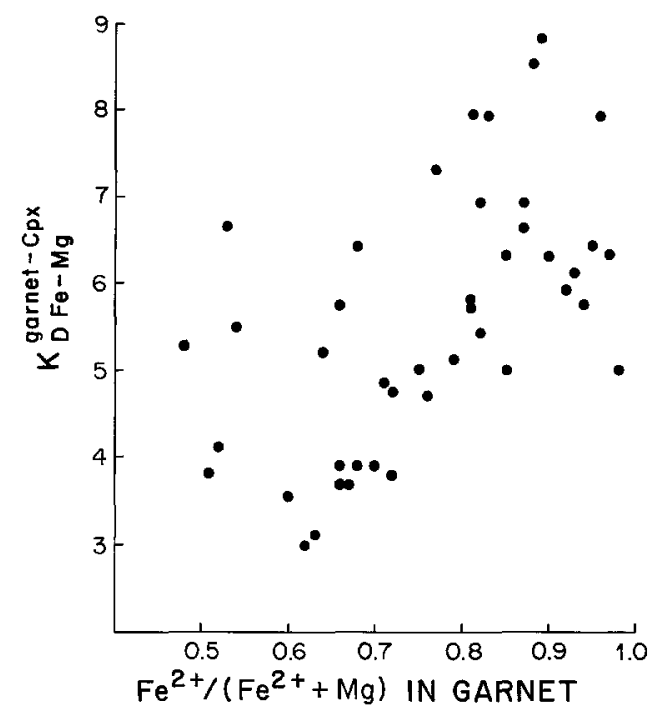

Fig. 6. $K_{D, \mathrm{Fe}-\mathrm{Mg}}^{\text {garnet-cpx }}$ vs. $\mathrm{Fe} / \mathrm{Mg}$ ratio for Adirondack garnet-clinopyroxene pairs

any possible dependence of $K_{D}$ on additional components such as Ca-, Ti-, Fe-Tschermaks, acmite, and jadeite components in clinopyroxenes that together can comprise up to $15 \%$ of some Adirondack clinopyroxenes. Simple plots of these components vs. $K_{D}$ show no correlations. There may be a slight negative correlation between $K_{D}$ and TiTschermaks component (higher the component, the lower the $K_{D}$ ) although the spread in the data are large. Coolen (1980) noted a rough positive correlation of $K_{D}$ with CaTschermaks component. A similar correlation is not observed in the Adirondack data. Also the strong correlation between $\mathrm{Mg} / \mathrm{Fe}^{2+}$ ratio and $K_{D}$ reported by Bohlen and Essene (1980) is still evident from our larger data base (Fig. 6), although there is somewhat greater scatter in the data. Despite the spread in the data, there appears to be a tendency for more magnesian bulk compositions to yield lower $K_{D}$. It is possible that at least some of the problems of accuracy and precision are related to this effect.

Other factors potentially affecting the calculated temperatures are analytical errors and errors in the estimation of $\mathrm{Fe}^{3+}$. To date there is no systematic study comparing the estimated $\mathrm{Fe}^{3+}$ iron contents of minerals with analytical determinations. However, for the analyses used in this study, there is a good correlation between the amount of $\mathrm{Fe}^{3+}$ in garnet and the amount in clinopyroxene that, at least indirectly, supports the scheme by which $\mathrm{Fe}^{3+}$ is determined and means that calculated temperatures differ by only a small amount $\left(<30^{\circ} \mathrm{C}\right)$ if one assumes either no $\mathrm{Fe}^{3+}$ or the estimated $\mathrm{Fe}^{3+}$ values. An error of $50 \%$ in the calculated $\mathrm{Fe}^{3+}$ contents of one of the minerals changes temperatures by less than $25^{\circ} \mathrm{C}$. In a similar way, small analytical errors of the sort to be expected with analyses obtained through use of the electron microprobe do not dramatically affect the calculated temperatures. For example, $\mathrm{a} \pm 3 \%$ error in analysis of $\mathrm{MgO}$ in garnet changes the calculated temperature by $\pm 15^{\circ} \mathrm{C}$. Therefore, aside from the possible effect of $\mathrm{Fe} / \overline{\mathrm{Mg}}$ ratio, it appears that in the Adirondacks, at least, there are no obvious reasons (such as mineral zonation, affects of minor components or analytical errors) for the imprecision of the garnet-clinopyroxene thermometers or the large differences between the results of the Dahl, Ganguly, Saxena calibrations and those of Ellis and Green.

There are six or seven garnet-clinopyroxene assemblages that yield unreasonably high temperatures in all four thermometer formulations. One is tempted to ascribe these anomalies to disequilibrium because the minerals have no unusual chemical characteristics that distinguish them from the other assemblages. However, distribution coefficients for $\mathrm{Ca}, \mathrm{Mn}, \mathrm{Ti}$, etc. between garnet and clinopyroxene and other phases such as orthopyroxene, amphibole and plagioclase are similar to those in other rocks for which garnetclinopyroxene temperatures are more reasonable. Even $\mathrm{Mg}$ / Fe distribution between orthopyroxene and clinopyroxene in these "anomalous" assemblages is essentially the same as that in the other assemblages, implying that the minerals in the assemblages are in equilibrium with respect to their $\mathrm{Mg}$ and $\mathrm{Fe}$ contents. Furthermore, pressures calculated from these "anomalous" assemblages using plagioclase(orthopyroxene-clinopyroxene)-garnet-quartz geobarometry (Newton and Perkins 1982, Bohlen et al. 1983) agree well with the pressure values obtained from the other assemblages. Therefore, if the unreasonable temperatures are the result of disequilibrium, it is manifest in a subtle manner.

It is somewhat surprising that in the Adirondacks the garnet-clinopyroxene thermometer that is the most accurate is the one that considers the fewest variables. In order to determine if the trends seen in the results of these thermometers are specific to the Adirondacks or are general, we have applied the four garnet-clinopyroxene thermometers in five other granulite terranes for which sufficient, highquality analytical data are avilable. Unfortunately, rigorous testing of the thermometers in other terranes is not always possible as a result of uncertainties in equilibration temperatures. Metamorphic temperatures in the granulite terranes of Greenland, Montana, New Zealand and Tanzania have been determined wholly or in large part by two-pyroxene geothermometry. The apparent undying faith in pyroxene thermometry is difficult to explain in light of several studies demonstrating both its inaccuracy and imprecision at metamorphic temperatures (Stormer and Whitney 1977; Lal et al. 1978; Bohlen and Essene 1979; Lindsley and Andersen 1983). These studies show that pyroxene geothermometry (Wood and Banno 1973; Wells 1977) yield scattered temperatures that generally are higher than other temperature data. Despite these problems, it is interesting to note that the trends observed in the Adirondacks are generally seen in other terranes. All thermometers seem to be imprecise although the Ellis and Green thermometer is substantially less so. In general, the Saxena temperatures are highest, well above the estimated equilibration temperatures (EET). The Ganguly and Dahl formulations also tend to give temperatures that appear to be too high. Ellis and Green temperatures, although somewhat scattered, are generally close to the EET, and in some cases, are in excellent agreement with other temperature data (Otter Lake, for example). Results from two field areas are of particular interest. In the Doubtful Sound terrane all garnet-clinopyroxene formulations give much greater temperatures than those inferred from Wood-Banno pyroxene thermometry. Secondly, data from the Ruby Range seem to indicate a marked effect of $\mathrm{Mn}$ on calculated Ellis \& Green temperatures, suggesting that this thermometer may underestimate temperature when garnets contain greater than $10 \mathrm{~mol} \%$ spessartine component. Study of Table 1 shows that in at 
least these six granulite terranes, the garnet-clinopyroxene geothermometer of Ellis and Green appears to give the most satisfactory results. The other calibrations give highly erratic and generally inaccurate temperatures, and their use elsewhere in their present form is not recommended.

We emphasize that our analysis of these four thermometers applies only to granulites containing garnets and clinopyroxenes whose compositions can be well described by $(\mathrm{Fe}-\mathrm{Mg}-\mathrm{Ca})_{3} \mathrm{Al}_{2} \mathrm{Si}_{3} \mathrm{O}_{12}$ and $(\mathrm{Ca}-\mathrm{Fe}-\mathrm{Mg})_{2} \mathrm{Si}_{2} \mathrm{O}_{6}$ respectively. The results of this study may not apply to rocks of greatly different thermal regimes and/or mineral chemistries. Indeed since the Ellis and Green thermometer does not consider the effects of large proportions of $\mathrm{Na}, \mathrm{Al}$ and $\mathrm{Mn}$ in clinopyroxene or Mn in garnet, the Ganguly or Saxena formulations may ultimately be the most accurate and widely applicable after considerable adjustment of calibration parameters.

Acknowledgments. This research was supported by National Science Foundation Grants EAR 75-22388 and EAR 78-23568 to EJE, and EAR 8206268 to SRB, a Sigma Xi Grant-in-Aid of Research to CAJ and by The Scott Turner Fund of The University of Michigan. The electron microprobe facilities at The University of Michigan are supervised by Professor Wilbur C. Bigelow of the Department of Metallurgy and Material Science, whose cooperation made this study possible. Several members of his staff, particularly L.F. Allard, S. Krause, and A.J. Mardinly gave assistance during data collection

\section{References}

Banno S (1970) Classification of eclogites in terms of physical conditions of their origin. Phys Earth Planet Int 3:405-421

Banno S, Matsui Y (1965) Eclogite types and partition of Mg, $\mathrm{Fe}$, and $\mathrm{Mn}$ between clinopyroxene and garnet. Proc Japan Acad $41: 716-721$

Bohlen SR, Boettcher AL (1981) Experimental investigations and geological applications of orthopyroxene geobarometry. Am Mineral 66:951-964

Bohlen SR, Essene EJ (1978a) Igenous pyroxenes from metamorphosed anorthosite massifs. Contrib Mineral Petrol 65:433-442

Bohlen SR, Essene EJ (1978b) The significance of metamorphic fluorite in the Adirondacks. Geochim Cosmochim Acta $42: 1669-1678$

Bohlen SR, Essene EJ (1979) A critical evaluation of two-pyroxene thermometry in Adirondack granulites. Lithos 12:335-345

Bohlen SR, Essene EJ (1980) Evaluation of coexisting garnet-biotite, garnet-clinopyroxene and other $\mathrm{Mg}-\mathrm{Fe}$ exchange thermometers in the Adirondacks. Bull Geol Soc Am pt II 91:685-719

Bohlen SR, Essene EJ, Hoffman KS (1980a) Update on feldspar and oxide thermometry in the Adirondack Mountains, New York. Bull Geol Soc Am pt I 91:110-113

Bohlen SR, Essene EJ, Boettcher AL (1980b) Reinvestigation and application of olivine-quartz-orthopyroxene barometry. Earth Planet Sci Lett 47:1-10

Bohlen SR, Wall VJ, Boettcher AL (1983) Experimental investigation and application of garnet granulite equilibria. Contrib Mineral Petrol 83:52-61

Brown PE, Essene EJ, Kelly WC (1978) Sphalerite geobarometry in the Balmat-Edwards district, New York. Am Mineral 63:250-257

Bryhni I, Griffin WL (1971) Zoning in eclogite garnets from Norfjord, West Norway. Contrib Mineral Petrol 32:112-125

Carswell DA, Gibb FGF (1980) Geothermometry of garnet lherzolite nodules with special reference to those from the kimberlites of Northern Lesotho. Contrib Mineral Petrol 74:403 416

Coleman RG, Lee DE, Beatty LB, Brannock WW (1965) Eclogites and eclogites: their differences and similarities. Bull Geol Soc Am 76:483-504
Coolen JJMMM (1980) Chemical petrology of the Furua granulite complex Southern Tanzania. GUA Papers in Geology (Amsterdam) Series $1: 13$

Dahl PS (1979) Comparative geothermometry based on major element and oxygen isotope distributions in Precambrian metamorphic rocks from southwestern Montana. Am Mineral 64:1280-1293

Dahl PS (1980) The thermal-compositional dependence of $\mathrm{Fe}^{2+}-$ Mg distribution between coexisting garnet and pyroxene: applications to geothermometry. Am Mineral 65:852-866

Dudley PP (1969) Electron microprobe analyses of garnet in glaucophane schists and associated eclogites. Am Mineral $54: 1139-1150$

Edwards RL, Essene EJ (1981) Zoning patterns and their effect on biotite-garnet $\mathrm{K}_{\mathrm{D}}$ thermometry. EOS Trans Am Geophys Un 62:411

Ellis DJ, Green DH (1979) An experimental study of the effect of $\mathrm{Ca}$ upon garnet-clinopyroxene $\mathrm{Fe}-\mathrm{Mg}$ exchange equilibria. Contrib Mineral Petrol 71:13-22

Essene EJ, Fyfe WS (1967) Omphacite in Californian metamorphic rocks. Contrib Mineral Petrol 15:1-23

Evans BW (1965a) Pyrope garnet-piezometer on barometer? Bull Geol Soc Am 76:1265-1300

Evans BW (1965b) Microprobe study of zoning in eclogite garnets. Abstr Geol Soc Am Spec Pap 87:54

Ganguly J (1979) Garnet and clinopyroxene solid solutions, and geothermometry based on $\mathrm{Fe}-\mathrm{Mg}$ distribution coefficient. Geochim Cosmochim Acta 43:1021-1029

Irving AJ (1974) Geochemical and high pressure experimental studies of garnet pyroxenite and pyroxene granulite xenoliths from the Delegate basaltic pipes, Australia. J Petrol 15:1-40

Johnson CA, Essene EJ (1982) The formation of garnet in olivinebearing metagabbros from the Adirondacks. Contrib Mineral Petrol $81: 240-251$

Lal RK, Ackerman D, Seifert F, Halder SL (1978) Chemographic relationships in sapphirine-bearing rocks from Sonapahar, Assam, India. Contrib Mineral Petrol 67:169-187

Lindsley, DH, Andersen DJ (1983) A two-pyroxene thermometer. J Geophys Res 88:A877-906

Lovering JF, White AJR (1969) Granulitic and eclogite inclusions from basaltic pipes at Delegate, Australia. Contrib Mineral Petrol 21:9-52

Mori T, Green DH (1978) Laboratory duplication of phase equilibria observed in natural garnet lherzolites. J Geol 86:83 97

Mysen BO, Heier KS (1972) Petrogenesis of eclogite in high grade metamorphic gneisses, exemplified by the Hareidland Eclogite, Western Norway. Contrib Mineral Petrol 36:73-94

Newton RC, Perkins D III (1982) Thermodynamic calibration of geobarometers for charnockites and basic granulites based on the assemblages garnet-plagioclase-orthopyroxene (clinopyroxene)-quartz with applications to high grade metamorphism. Am Mineral 67:203-222

Oka Y, Matsumoto T (1974) Study on the compositional dependence of the apparent partition coefficient of iron and magnesium between coexisting garnet and clinopyroxene solid solution. Contrib Mineral Petrol 48:115-121

Oliver GJH (1977) Feldspathic hornblende and garnet granulites and associated anorthosite pegmatites from Doubtful Sound, Fiordland, New Zealand. Contrib Mineral Petrol 65:111-121

Perkins D (1979) Application of new thermodynamic data to mineral equilibria. Ph.D. thesis University of Michigan

Podpora C, Lindsley DH (1979) Fe-rich pigeonites: minimum temperatures of stability in the $\mathrm{Ca}-\mathrm{Mg}-\mathrm{Fe}$ quadrilateral. Trans Am Geophys Un 60:420-421

Raheim A, Green DH (1974) Experimental determination of the temperature and pressure dependence of the $\mathrm{Fe}-\mathrm{Mg}$ partition coefficient for coexisting garnet and clinopyroxene. Contrib Mineral Petrol 48:179-203

Rucklidge JC, Gasparrini EL (1969) Specifications of a complete program for processing electron microprobe data: EMPADR VII. Dept. of Geology, University of Toronto, unpubl circular 
Saxena SK (1968) Distribution of iron and magnesium between coexisting garnet and clinopyroxene in rocks of varying metamorphic grade. Am Mineral 53:2018-2024

Saxena SK (1969) Silicate solid solutions and geothermometry. 4. Stability study of chemical data on garnets and clinopyroxene. Contrib Mineral Petrol 23:140-156

Saxena SK (1979) Garnet-clinopyroxene geothermometer. Contrib Mineral Petrol 70:229-235

Stoddard EF (1976) Granulite facies metamorphism in the ColtonRainbow Falls area, northwest Adirondacks, New York. PhD thesis University of California, Los Angeles

Stoddard EF (1980) Metamorphic conditions at the northern end of the northwest Adirondack Lowlands. Bull Geol Soc Am $91: 97-100$

Stormer JC, Whitney JA (1977) Two-feldspar geothermometer in granulite facies metamorphic rocks. Contrib Mineral Petrol $65: 123-133$

Valley JW, Essene EJ (1980a) Calc-silicate reactions in Adirondack marbles: the role of fluids and solid solutions. Bull Geol Soc Am $91: 720-815$

Valley JW, Essene EJ (1980b) Akermanite in the Cascade Slide xenolith and its significance for regional metamorphism in the Adirondacks. Contrib Mineral Petrol 74:143-152
Valley JW, O'Neil JR (1981) ${ }^{13} \mathrm{C} /{ }^{12} \mathrm{C}$ exchange between calcite and graphite: a possible thermometer in Grenville marbles. Geochim Cosmochim Acta 45:411-419

Wells PRA (1977) Pyroxene thermometry in simple and complex systems. Contrib Mineral Petrol 62:129-139

Wells PRA (1979) Chemical and thermal evolution of Archaean sialic crust, southern West Greenland. J Petrol 20:187-226

Wood BJ (1975) The influence of pressure, temperature and bulk composition on the appearance of garnet in orthogneisses-an example from South Harris, Scotland. Earth Planet Sci Lett $26: 299-311$

Wood BJ (1976) The partitioning of iron and magnesium between coexisting garnet and clinopyroxene. Ann Rep Dir Carnegie Inst Washington Yearb 75:571-574

Wood BJ (1977) The activities of components in clinopyroxene and garnet solid solutions and their application to rocks. Philos Trans R Soc London Ser A 286:331-342

Wood BJ, Banno S (1973) Garnet-orthopyroxene and orthopyroxene-clinopyroxene relationships in simple and complex systems. Contrib Mineral Petrol 42:109-124

Accepted May 26, 1983 